\title{
DIGITALIZATION OF BUSINESS REGISTER
}

\author{
Željka Bregeš * \\ Tina Jakupak**
}

\begin{abstract}
The authors in this paper analyze new system and possibilities that will rise for the companies and citizens regarding the digitalization of the market and business register. From June 2017, business registers in all EU countries are interconnected. This means that anybody can search for information on companies registered in any EU country. We can also search for companies in Iceland, Liechtenstein or Norway. Very important is that the registers can share information on foreign branches and cross-border mergers of companies. This system - Business Registers Interconnection System (BRIS) - is a joint effort by EU governments and the European Commission. This paper introduces the cooperation of business registers at European level.
\end{abstract}

KEYWORDS: EU company law, business register, digitalization, BRIS

\section{INTRODUCTION}

Over 10 million citizens are involved in cross-border judicial procedures each year. ${ }^{1}$ That means a greater need for cooperation between different national judicial systems, and improved access to information on the judicial process in different European countries.

Businesses expand beyond national borders, using the opportunities offered by the internal market. Because of that there is an increasing demand for access to information on companies in a cross-border context. Very often offi-

\footnotetext{
* Judge at Commercial Court Zagreb, Court Register; zeljka.breges@tszg.pravosudje.hr

** Judge at Commercial Court Zagreb, Court Register; tina.jakupak@tszg.pravosudje.hr

1 https://ec.europa.eu/cefdigital/wiki/display/CEFDIGITAL/2017/06/07/European+e-Justice +Portal -visited on 25th Aug, 2017
} 
cial information on companies is not always readily available on a cross-border basis. ${ }^{2}$

The European e-Justice Portal ${ }^{3}$ facilitates this cooperation by providing information and access to justice services across the EU.

The European Access Point to the interconnection of the national business registers (Business Registers Interconnection System - BRIS) is now, from 8 June 2017, available on the European e-Justice Portal. ${ }^{4}$

EU citizens, and all others, can now search from the Portal within the national registers of $10 \mathrm{EU} / \mathrm{EEA}$ Member States and this number will steadily increase when more countries' implementations become fully operational. One of the member states which are already in BRIS is Croatia.

\section{DEVELOPMENT OF BRIS}

28 EU member states have different legal systems and they have as many different possibilities for companies. This is one of the main reasons for the harmonization and digitalization of business register.

The need for cross-border cooperation of business registers was identified nearly two decades ago, which led to the launching of the so-called European Business Register (EBR) initiative. This was voluntary project undertaken by the business registers with the support of the European Commission ${ }^{5}$. After that came Business Register Interoperability Throughout Europe (BRITE) and the Internal Market Information System (IMI). Finally, came of initiative the e-Justice which aim was to assist the work of judicial authorities or practitioners and facilitate the access of citizens to judicial, legal information.

The European e-Justice Portal was introduced to improve citizens' access to justice, to facilitate procedures within the EU and to make the resolution of disputes or the punishment of criminal behavior more effective ${ }^{6}$.

\footnotetext{
2 Commission communication to The European parliament, The Council, The Economic and social committee and the committee of the regions A coherent framework for building trust in the Digital Single Market for e-commerce and online services /* COM/2011/0942 final *

3 https://e-justice.europa.eu/content_business _registers_at_european_level-105-en.do-visited on 25th Aug, 2017

4 Ibid 1,3

5 Report on digitalization in company law, ICLEG, March 2016; Green Paper - The interconnection of business registers \{SEC(2009) 1492\}Green Paper - The interconnection of business registers $\{$ SEC(2009) 1492\}/* COM/2009/0614 final */

6 Ibid 1,3
} 
In 2012, European Commission launched an Action Plan on company law and corporate governance which supported three key objectives: enhancing transparency, engaging shareholders and supporting companies' growth and their competitiveness. The proposal was also to launch a company law codification in order to make the regulatory framework more user-friendly ${ }^{7}$.

In the past years, the cross-border dimension of business has grown from a company and a consumer perspective. In order to take a proper decision the information is needed. The business register contains official information on the companies which refers to all particularly important matters, reports defined by the law ${ }^{8}$.

In Europe, business registers offer a range of services different from one Member State to another. However, the core services provided by all registers are to register, examine and store company information, such as information on a company's legal form, its seat, capital and legal representatives, and to make this information available to the public ${ }^{9}$.

European Commission has made a survey on business registers in 2013 and reached following data and information ${ }^{10}$ :

A. concerning business registers covered by the Directive ${ }^{11}$ :

- 18 (67\%) member states have only one central business register

- 7 member states have one central business register plus other regional or local registers (the ones with regional registers have no local registers and vice-versa)

- 2 member states do not have a central register but have regional and/or local registers, and they are interconnected;

\footnotetext{
7 Communication from the Commission to the European parliament, the Council, the European economic and social committee and the committee of the regions Action Plan: European company law and corporate governance - a modern legal framework for more engaged shareholders and sustainable companies/* COM/2012/0740 final */

$8 \quad$ Ibid 7

9 Ibid 3

10 www.ecrforum.org/wp.../1-BRIS-Mrs-Magda-Talaban-EU.pptx visited on 27th Aug, 2017

11 Directive 2012/17/EU of the European Parliament and of the Council of 13 June 2012 amending Council Directive 89/666/EEC and Directives 2005/56/EC and 2009/101/EC of the European Parliament and of the Council as regards the interconnection of central, commercial and companies registers, http://eur-lex.europa.eu/legal-content/EN/TXT/?uri=CELEX:32012L0017 OJ L 156, 16.6.2012, p. 1-9
} 
B. concerning documents and particulars disclosed by business registers:

- $19(70 \%)$ member states disclose a rich range of other documents and information beyond those required by Directive 2009/101/EC ${ }^{12}$;

C. concerning Company Unique Identifier:

- less than half of the member states use Unique Identifiers for registering companies, different from the Registration Number.

As a result, BRIS is ensuring the availability of information on companies registered in any EU member state and EEA country.

BRIS is a part of the European e-Justice Portal, the one-stop-shop for citizens, businesses and legal professionals across Europe.

The BRIS infrastructure is a joint effort by EU governments and the European Commission. It facilitates public access to information on European companies and ensures that all European business registers can communicate with each other electronically in a safe and secure way.

The aim of BRIS is to enhance confidence in the single market through transparency and up-to-date information and reduce unnecessary burdens on companies $^{13}$.

The jurisprudence of the European Court of Justice has opened up the possibility for businesses to incorporate in one Member State and conduct their business activity either partly or entirely in another Member State ${ }^{14}$.

12 Directive 2009/101/EC of the European Parliament and of the Council of 16 September 2009 on coordination of safeguards which, for the protection of the interests of members and third parties, are required by Member States of companies within the meaning of the second paragraph of Article 48 of the Treaty, with a view to making such safeguards equivalent (Text with EEA relevance), No longer in force, OJ L 258, 1.10.2009, p. 11-19

13 https://e-justice.europa.eu/content_business_registers-104--maximize-en.do https://ec.europa.eu/cefdigital/wiki/display/CEFDIGITAL/2017/06/19/BRIS+Now+Live+on+the+European+eJustice +Portal-visited on 25th Aug, 2017

14 H. Horak, K. Dumančić, K. Poljanec, "The interconnection of company data - a way forward in development of freedom of establishment?," International 4th OFEL Conference on Governance, Management and Entrepreneurship „New Governance for value creation towards stakeholding and participation“, Dubrovnik, Croatia, 14-16 April 2016; H. Horak, K. Dumančić, K. Poljanec, "Neusklađenost prava pripajanja i spajanja na unutarnjem tržištu EU kao prepreka slobodi poslovnog nastana,” Zbornik radova sa znanstvenog skupa „Zakon o trgovačkim društvima - 20 godina primjene u interdisciplinarnom okruženju“, Faculty of economics and business Zagreb, 2015, http://web.efzg.hr/dok/KID//Zbornik\%20trg.\%20drustva.pdf; Centros C-212/97 [1999] ECLI:EU:C:1999:126; Überseering C-208/00 [2002] ECLI:EU:C:2002:632; Inspire Art C-167/01 [2003] ECLI:EU:C:2003:512; Horak, Hana; Dumančić, Kosjenka; Poljanec, Kristijan: Principle of Transparency as Integrative Factor of the Internal Market and Har- 


\section{LEGAL BASIS AND TECHNICAL DATA}

The term »Digitalization « is the representation of communication in writing or sound by electronic means and the concept thus concerns electronic communication including the transmission of information and the storage of such communication electronically and electronic access and retrieval from such storage ${ }^{15}$.

The term "Business register" comprises the national commercial registers, companies' registers, and any other register storing company information and making it available to the public within the meaning of Directive 2009/101/EC ${ }^{16}$.

The gold of BRIS is to access to up-to-date and official information on companies. Business registers play an essential role in this regard. Business register, examine and store company information, such as information on a company's legal form, its seat, capital and legal representatives, and they make this information available to the public. They may also offer additional services, which may vary from one country to another. The minimum standards of the core services are set by European legislation ${ }^{17}$; in particular Member States have to maintain electronic business registers ${ }^{18}$ since 1 January 2007. Business registers in Europe operate on a national or regional basis: they only store information on companies registered in the territory (country or region) where they are competent.

The system (BRIS) consists of:

- A core services platform, named "European Central Platform" (ECP);

- The Member States business registers and Iceland, Liechtenstein or Norway; and

monisation of Croatian Law on Companies Registries. // International law readings3 (2014.), 14; 170-195; Horak, Hana; Dumančić, Kosjenka, Transparency and Disclosure as key elements for companies and markets u: Horak, Hana (ed.), 2nd International Conference: Legal and Economic Aspects of Corporate Governance - Market Transparency and Disclosure in Private and Public Companies, Proceedings, Zagreb, 2013.

15 Ibid 5

16 Ibid 12

17 Directive 68/151/EEC of 9 March 1968 on co-ordination of safeguards which, for the protection of the interests of members and others, are required by Member States of companies within the meaning of the second paragraph of Article 58 of the Treaty, with a view to making such safeguards equivalent throughout the Community (OJ L 65, 14.3.1968, p. 8); last amended by Directive 2003/58/EC of the European Parliament and of the Council of 15 July 2003 (OJ L 221, 4.9.2003, p. 13).

18 Directive 2003/58/EC of the European Parliament and of the Council of 15 July 2003 amending Council Directive 68/151/EEC, as regards disclosure requirements in respect of certain types of companies (OJ L 221, 4.9.2003, p. 13). 
- The e-Justice portal which provides an interface serving as European electronic access point to information on companies. ${ }^{19}$

ECP is connected with the e-Justice portal. European Commission administers and manages this portal.

This Portal functions as European Access Point (EAP) for public for information about all business register across EU.

Legal basis for BRIS were set out by Directive 2012/17/EU on the interconnection of business registers ${ }^{20}$ and the Commission Implementing Regulation (EU) $2015 / 884$ of 8 June $2015^{21}$.

The directive requires the establishment of an information system that interconnects the central, commercial and companies registers (also referred to as business registers) of all Member States. The directive accents need to improve transparency and access to company information at EU level and need to provide updated reliable information on companies and their foreign branches. The Regulation details the technical specifications for the system.

Citizens may request any of documents, available in business registers and they will be provided.

Anybody can get information about companies registered in business registers in the EU, Iceland, Liechtenstein or Norway using the 'Find a company' service on e-Justice portal.

At the moment citizens and others can only request information that the national registers provide free of charge. You can also find links to webpages of national registries ${ }^{22}$.

\footnotetext{
19 https://ec.europa.eu/cefdigital/wiki/pages/ viewpage.action?pageId=46992657 visited on 25th Aug, 2017

20 Ibid 11

21 Regulation (EU) 2015/884 of 8 June 2015 establishing technical specifications and procedures required for the system of interconnection of registers established by Directive 2009/101/ EC of the European Parliament and of the Council OJ L 144, 10.6.2015, p. 1-9 ELI: http://data. europa.eu/eli/reg_impl/2015/884/oj

22 https://e-justice.europa.eu/content_find_ a_company-489-EU-maximize en.do?idSubpage $=1 \&$ member $=1 \#$ n06 visited on 25th Aug, 2017
} 


\section{CONCLUSION}

From the beginning (June 2017), the business register of Croatia (Court Register) is part of BRIS ${ }^{23}$. Through e-Justice Portal you can search for information on companies registered in Croatia and 9 other countries. Consumers, creditors and other business partners can access to all basic information free of charge-name of company, companies' registers number, seat, country, EUID, etc.

The gold of BRIS is accomplished for companies registered in Croatia: to increase confidence of EU member states and its citizens and others in the Single Market by ensuring a safer business environment for consumers, creditors and other business partners; and to access to up-to-date and official information on companies.

BRIS provides a higher degree of legal certainty as to the information in the European business registers and help improve the cooperation between business registers in Europe for procedures concerning cross-border mergers, and the exchange of relevant information regarding companies and their branches.

As soon as all of the member states will connect, BRIS will definitely increase legal certainty and confidence in the internal market. To facilitate access to information on companies across borders, all member states need to participate to make network of business registers whole.

The digitalization of business register is expected to bring the easier and transparent functioning of the transfer of data especially across the border and to implement possibilities of electronical correspondence in everyday work.

The BRIS enhance transparency and gives possibility for gaining information in the EU.

The EU company law needs to recognize technical developments further and develop more technological possibilities to ensure that companies, citizens and authorities benefit from the digital age. There should be more usage of opportunities offered by digital technology that has no (cross) border.

23 https://sudreg.pravosudje.hr/ 


\section{LITERATURE:}

\section{BOOKS AND ARTICLES/PAPERS}

1. H. Horak, K. Dumančić, K. Poljanec, "The interconnection of company data a way forward in development of freedom of establishment?," International 4th OFEL Conference on Governance, Management and Entrepreneurship „New Governance for value creation towards stakeholding and participation“, Dubrovnik, Croatia, 14-16 April 2016

2. H. Horak, K. Dumančić, K. Poljanec, "Neusklađenost prava pripajanja i spajanja na unutarnjem tržištu EU kao prepreka slobodi poslovnog nastana," Zbornik radova sa znanstvenog skupa „Zakon o trgovačkim društvima - 20 godina primjene u interdisciplinarnom okruženju“, Faculty of economics and business Zagreb, 2015, http://web.efzg.hr/dok/KID//Zbornik\%20trg.\%20drustva.pdf

3. Horak, Hana; Dumančić, Kosjenka; Poljanec, Kristijan: Principle of Transparency as Integrative Factor of the Internal Market and Harmonisation of Croatian Law on Companies Registries. // International law readings3 (2014.) , 14; 170-195

4. Horak, Hana; Dumančić, Kosjenka, Transparency and Disclosure as key elements for companies and markets u: Horak, Hana (ed.), 2nd International Conference: Legal and Economic Aspects of Corporate Governance - Market Transparency and Disclosure in Private and Public Companies, Proceedings, Zagreb, 2013

\section{LEGAL ACTS}

1. Directive 2012/17/EU of the European Parliament and of the Council of 13 June 2012 amending Council Directive 89/666/EEC and Directives 2005/56/EC and 2009/101/EC of the European Parliament and of the Council as regards the interconnection of central, commercial and companies registers, http://eur-lex.europa. eu/legal-content/EN/TXT/?uri=CELEX:32012L0017 OJ L 156, 16.6.2012, p. 1-9

2. Directive 2009/101/EC of the European Parliament and of the Council of 16 September 2009 on coordination of safeguards which, for the protection of the interests of members and third parties, are required by Member States of companies within the meaning of the second paragraph of Article 48 of the Treaty, with a view to making such safeguards equivalent (Text with EEA relevance), No longer in force, OJ L 258, 1.10.2009, p. 11-19

3. Directive 68/151/EEC of 9 March 1968 on co-ordination of safeguards which, for the protection of the interests of members and others, are required by Member States of companies within the meaning of the second paragraph of Article 58 of the Treaty, with a view to making such safeguards equivalent throughout the Community (OJ L 65, 14.3.1968, p. 8); last amended by Directive 2003/58/EC of the European Parliament and of the Council of 15 July 2003 (OJ L 221, 4.9.2003, p. 13). 
4. Directive 2003/58/EC of the European Parliament and of the Council of 15 July 2003 amending Council Directive 68/151/EEC, as regards disclosure requirements in respect of certain types of companies (OJ L 221, 4.9.2003, p. 13)

5. Regulation (EU) 2015/884 of 8 June 2015 establishing technical specifications and procedures required for the system of interconnection of registers established by Directive 2009/101/EC of the European Parliament and of the Council OJ L 144, 10.6.2015, p. 1-9 ELI: http://data.europa.eu/eli/reg_impl/2015/884/oj

\section{OTHER SOURCES}

1. https://ec.europa.eu/cefdigital/wiki/display/CEFDIGITAL/2017/06/07/European+ e-Justice+Portal -visited on 25th Aug, 2017

2. Commission communication to The European parliament, The Council, The Economic and social committee and the committee of the regions A coherent framework for building trust in the Digital Single Market for e-commerce and online services /* COM/2011/0942 final */

3. https://e-justice.europa.eu/content_business_registers_at_european_level-105en.do-visited on 25th Aug, 2017

4. Report on digitalisation in company law, ICLEG, March 2016

5. Green Paper - The interconnection of business registers $\{\operatorname{SEC}(2009) 1492\}$ Green Paper - The interconnection of business registers \{SEC(2009) 1492\}/* COM/2009/0614 final */

6. Communication from the Commission to the European parliament, the Council, the European economic and social committee and the committee of the regions Action Plan: European company law and corporate governance - a modern legal framework for more engaged shareholders and sustainable companies/* $\mathrm{COM} / 2012 / 0740$ final */

7. www.ecrforum.org/wp.../1-BRIS-Mrs-Magda-Talaban-EU.pptx visited on 27th Aug, 2017

8. https://e-justice.europa.eu/content_business_registers-104--maximize-en. do https:/ec.europa.eu/cefdigital/wiki/display/ CEFDIGITAL/2017/06/19/ BRIS+Now+Live+on+the+European+e-Justice+Portal-visited on 25th Aug, 2017

9. Centros C-212/97 [1999] ECLI:EU:C:1999:126;

10. Überseering C-208/00 [2002] ECLI:EU:C:2002:632;

11. Inspire Art C-167/01 [2003] ECLI:EU:C:2003:512;

12. https://ec.europa.eu/cefdigital/wiki/pages/viewpage. action?pageId=46992657 visited on 25th Aug, 2017

13. https://e-justice.europa.eu/content_find_a_company-489-EU-maximize en.do?idSubpage $=1 \&$ member=1\#n06 visited on 25th Aug, 2017

14. https://sudreg.pravosudje.hr/ 
